\title{
Akut Lösemi Hastalarında Alopesinin Beden İmajı ve Benlik Saygısına Etkisi*
}

\author{
Seda PEHLIVAN ${ }^{1}$, Dilek DOĞAN ${ }^{2}$, Beyza Nur KAHRAMAN ${ }^{3}$, Fahir ÖZKALEMKAŞ $^{4}$ \\ 1 Bursa Uludağ Üniversitesi Sağlık Bilimleri Fakültesi, Hemşirelik Bölümü, İç Hastalıkları Hemşireliği \\ Anabilim Dalı, Bursa. \\ 2 Bursa Orhaneli Devlet Hastanesi, Bursa. \\ 3 Kütahya Dumlupınar Üniversitesi, Evliya Çelebi Eğitim Araştırma Hastanesi, Kütahya. \\ 4 Bursa Uludağ Üniversitesi Tıp Fakültesi, İç Hastalıkları Anabilim Dalı, Hematoloji Bilim Dalı, Bursa.
}

\section{ÖZET}

Çalı̧ma, akut lösemi hastalarında alopesinin beden imajı ve benlik saygısına etkisini belirlemek ve sağlıklı bireylerle karşılaştırmak amacıyla planlandı. Tanımlayıcı nitelikte olan çalışmaya, 6 aylık sürede hematoloji polikliniği, kliniği ve ayaktan kemoterapi ünitesinde tedavi gören 91 akut lösemi hastası ile 94 sağlıklı birey dahil edildi. Calışmanın verileri, Hasta/Sağlıklı Bilgi Formu, Kemoterapiye Bağlı Alopeside Yaşam Kalitesi Ölçeği (KBAYKÖ), Rosenberg Benlik Saygısı Ölçeği ve Beden İmajı Ölçeği ile toplandı. Verilerin değerlendirilmesinde; SPSS kullanılarak, yüzdelik, ki-kare, student $t$ testi, ANOVA ve Pearson korelasyon analizleri yapıldı. Alopesi görülme oranı akut lösemi hastalarında \%63.7, sağlıklı bireylerde ise \%57.4 olarak bulundu ( $\mathrm{p}>0.05)$. Ancak alopesi düzeyinin hastaların \%84.5'inde gözle açıkça görülebilir, sağlıklı bireylerde ise \% 75 'inde gözle belli belirsiz görülebilir şeklinde olduğu saptandı $(p=0.000)$. Hastaların genel sağlık puanı ile benlik saygısı $(\mathrm{p}=0.000)$ ve beden imajı $(\mathrm{p}=0.000)$ arasında pozitif ilişki olduğu belirlendi. Alopesinin akut lösemi hastalarında benlik saygısını olumsuz etkilediği, beden imajını etkilemediği saptandı. Akut lösemi hastalarında genel sağlık ile ilişkisi göz önüne alındığında, alopesinin hastalar üzerindeki etkisi, benlik saygısı ve beden imajının değerlendirilmesinin gerektiği düşünülmektedir.

Anahtar Kelimeler: Akut lösemi. Alopesi. Benlik saygısı. Beden imajı.

The Effect of Alopesia on Body Image and Self-Esteem in Acute Leukemia Patients

\section{ABSTRACT}

The aim of study was to determine the effect of alopecia on body image and self-esteem in acute leukemia patients and to compare with healthy individuals. The descriptive study was performed at the hematology outpatient polyclinic, clinic and chemotherapy unit within 6 months. 91 patients with acute leukemia and 94 healthy individuals were included in the study. Data were collected by Patient/Healthy Information Form, Chemotherapy Induced Alopecia Quality of Life Scale (CIAQLS), Rosenberg Self-Esteem Scale and Body Image Scale. Percentage, chi-square, student $t$ test, ANOVA and Pearson correlation analyzes were performed by using SPSS. The rate of alopecia was $63.7 \%$ in acute leukemia patients and $57.4 \%$ in healthy individuals ( $>0.05$ ). However, alopecia level was found clearly seen in $84.5 \%$ of the patients and visibly invisible $75 \%$ in healthy individuals $(\mathrm{p}=0.000)$. It was determined that there was a positive relationship between the general health score of the patients and self-esteem and body image $(\mathrm{p}=0.000)$. Alopecia had negative effects on self-esteem in patients with acute leukemia and did not affect body image. Considering its relationship with general health in patients with acute leukemia, the effect of alopecia on patients, self-esteem and body image are thought to be evaluated.

Key Words: Acute leukemia. Alopecia. Self-esteem. Body image.

Geliş Tarihi: 29 Nisan 2019

Kabul Tarihi: 30 Mayıs 2019

* I. Uluslararası İç Hastalıkları Hemşireliği Kongresi'nde sözel bildiri olarak sunulmuştur (25-27 Kasım 2018, Antalya).

Dr. Seda PEHLIVAN

Bursa Uludağ Üniversitesi Sağlık Bilimleri Fakültesi, Hemşirelik Bölümü, İç Hastalıkları Hemşireliği AD,

Nilüfer BURSA

Tel.: 42462, 05055912165

E-posta: pehlivans@uludag.edu.tr
Ülkemizde kanser insidansı 2014 yılında yüz binde 210.2 olarak bulunurken, hematolojik malignitelerin insidansının kadınlarda yüz binde 12.6 ve erkeklerde yüz binde 18.2 olduğu bildirilmiştir. Lösemiler ise; hematolojik maligniteler arasında ikinci sırada yer almaktadır ${ }^{1}$. Kemik iliği ve kan kanseri olarak tanımlanan lösemi, akut ve kronik olarak ayrılmaktadır ${ }^{2}$. Löseminin tedavisinde kullanılan antineoplastik tedavilere bağlı olarak hastalarda görülebilen yan etkiler; lökopeni, trombositopeni, anemi, ağrı, yorgunluk, alopesi, bulantı/kusma, uyku bozuklukları, mukozit ve konstipasyondur ${ }^{2,3}$. Kanser tanısı almış olmanın yanı 


\section{S. Pehlivan, ark.}

sıra yaşanan bu yan etkiler, hastalarda anksiyete, depresyon, ağrı, seksüel fonksiyon bozukluğu, yorgunluk, benlik kavramında değişme, beden imajından rahatsızlık gibi semptomların ortaya çıkmasına neden olmaktadır. Bu durumda hastaların olağan uyum mekanizmaları sarsılır, geleceğe yönelik beklenti/planları bozulmakta ve sonuçta yaşam kalitesi olumsuz etkilenmektedir $^{3,4}$.

İnsan vücudunda hayati bir biyolojik fonksiyonu olmasa da saç, vücut örtüsünün önemli bir parçasıdır. Saç, hem erkek hem de kadınlarda beden imajı ve kendini tanımlamada oynadığı önemli rol nedeniyle psikolojik değere sahiptir ${ }^{5}$. Kemoterapinin istenmeyen etkilerinden biri olan alopesiye bağlı olarak hastalar anksiyete, depresyon, negatif beden imajı ve düşük benlik saygısı gibi sorunlar yaşamaktadır ${ }^{3}$. Kanser ve uygulanan tedaviler, bireyin iyilik halini olumsuz etkilemekte ve yaşanan semptomlar bireyin psikolojik/bedensel bütünlügüne yönelik tehditlere neden olmaktadir ${ }^{6}$.

Beden imaj1, kanserden etkilenen birey için merkezi öneme sahiptir. Beden imajında bozulma, hastaların duygusal yönünün yanı sıra fonksiyonel organların işlevlerinin de olumsuz etkilenmesine neden olabilmektedir. Beden imajının bozulduğu durumlarda, olumsuz etkilenmenin azaltılabilmesi için hastanın işlevsel olan fonksiyonlarının desteklenmesi ve erken psikososyal desteğin sağlanması gerekmektedir ${ }^{6}$. Beden imajı ile benlik saygısı arasında önemli bir ilişki olduğu bildirilmektedir. Benlik saygısı, kișinin kendi değerini ve özgüvenini duygusal olarak değerlendirmesini ifade ettiğinden kendisine duyduğu saygıyı tanımlanmaktadır. Bozulmuş benlik saygısı, kanser hastalarında sıklıkla karşılaşılan istenmeyen bir durumdur $^{2,7}$. Akut lösemi hastaları ile yapılan bir çalışmada, depresyon ve umutsuzluk düzeylerinin yüksek olduğu, depresyon ve umutsuzluk birbiriyle ilişkili olsa da, yapılan çok değişkenli analizde umutsuzluğun yaşlılık ve benlik saygısı ile ilişkili olduğunu bulunmuştur ${ }^{8}$. Benlik saygısının, hastalıklarla karşılaşma ve baş etme sürecinde oynadığı önemli rol nedeniyle değerlendirilmesi gerektiği vurgulanmaktadır ${ }^{3}$.

Hematolojik malignitesi olan bireylerin, iyilik halini yeniden kazanmalarına yardımcı olmak, iç/dış baş etme yöntemlerini güçlendirmek ve kısa zamanda normale dönmelerini kolaylaştırmak için destekleyici bakım oldukça önemlidir ${ }^{4}$. Bu doğrultuda hemşirelik bakımında, hematolojik malignitesi olan hastaların duygusal durumlarına daha fazla dikkat edilmesi gerektiği vurgulanmaktadır ${ }^{2,4}$. Hastalık ve tedavi sürecindeki önemi göz önüne alındığında; kanser tanısı ve tedavisi alan hastaların beden imajı ve benlik saygıs düzeyinin ve etkileyen faktörlerin değerlendirilmesinin önemli olduğu düşünülmektedir. Literatürde; erişkin lösemi hastalarında saç dökülmesinin beden imajı ve benlik saygısına etkisinin araştırıldı̆̆ rastlanmamıştır. Bu doğrultuda çalışma, akut lösemi hastalarında alopesinin beden imaj1 ve benlik saygıs1na etkisini belirlemek ve sağlıklı bireylerle karşılaştırmak amacıyla yapıldı.

\section{Gereç ve Yöntem}

Tanımlayıcı ve kesitsel nitelikte olan çalışma, 01/03/2018 tarihinden itibaren 6 aylık sürede bir üniversite hastanesinin hematoloji bilim dalının poliklinik, klinik ve ayaktan kemoterapi ünitesinde takip ve tedavi edilen hastalar ile yapıldı. Çalışmaya, araştırmanın uygulama süresi içinde ulaşılabilen ve çalışmaya katılmayı kabul eden toplam 91 akut lösemi hastası dahil edildi. Çalışmaya katılmayı kabul etmeyen, ek hastalığ1 olan, iletişim problemi ya da psikiyatrik hastalığ 1 olan ve anketin tamamını dolduramayanlar çalışma dışında bırakıldı. Ayrıca bilinen herhangi bir kronik/psikiyatrik hastalığı olmayan, hematoloji kliniği dışındaki hastaların yakınları ve hematoloji kliniği dışında hastanenin diğer çalışanlarından, çalışmaya katılmayı kabul eden 94 sağlıklı birey sağlıklı kontrol grubuna alındı. Sağlıklı kontrol grubundan elde edilen veriler, hastaların verileri ile karşılaştırıldı.

\section{Veri Toplanması}

Hastaların verileri, araştırmacılar tarafından hazırlanan Hasta Bilgi Formu, Kemoterapiye Bağlı Alopeside Yaşam Kalitesi Ölçeği, Rosenberg Benlik Saygısı Ölçeği ve Beden İmajı Ölçeği ile toplandı. Sağlıklı bireylere ise; araştırmacılar tarafından hazırlanan Sağlıklı Birey Bilgi Formu, Rosenberg Benlik Saygısı Ölçeği ve Beden İmajı Ölçeği uygulandı.

Hasta Bilgi Formu: hastaya ait sosyodemografik ve hastalık özelliklerinin yanı sıra tedavinin etkileri ve saç dökülmesine ilişkin 27 sorudan oluşmaktadır.

Săğlklı Birey Bilgi Formu: bireye ait sosyodemografik özellikler ve saç dökülmesine ilişkin 16 soru bulunmaktadır.

Genel Să̆lık Değerlendirmesi: Çalıșmaya katılan tüm bireylerden, görsel analog skala ile “çok kötü”den "çok iyi” seviyeye giden çizgi üzerinde genel sağlık durumunu en iyi ifade eden yeri işaretlemesi istendi. Skalanın değerlendirmesi, $0=$ çok kötü ve $10=$ çok iyi olacak şekilde araştırmacı tarafından ölçülerek yapıldı.

Kemoterapiye Bağll Alopeside Yaşam Kalitesi Ölçeği (KBAYKÖ): Akbal Ateş ve Olgun (2011) tarafindan geliştirilen beşli likert tipinde hazırlanmış 19 soruluk bir ölçektir. Ölçek, alopesinin hastanın yaşamına olumsuz etkilerine ilişkin ifadelerin yer aldığ "Genel Yaşama Olan Yansımaları Boyutu” (9-45 puan), iç dünyasındaki olumsuz etkilerine ilişkin ifadelerin yer aldığı "İç Dünyaya Olumsuz Yansımaları Boyutu" (630 puan), tersinden puanlanan ve olumlu ifadelerin yer aldığg "Pozitif Düşünceler Boyutu" (4-20 puan) olmak üzere toplam üç alt boyuttan oluşmaktadır. Ölçekten 


\section{Akut Lösemi ve Alopesi}

alınan düşük puanlar hastaların yaşam kalitesindeki bozulmayı işaret etmektedir. Ölçekten alınacak puan 19-95 arasında değişmektedir. Ölçeğin cronbach alfa katsayısı 0.88 olarak bulunmuştur ${ }^{3}$. Çalışmamızda ise cronbach alfa katsayısı 0.82 bulundu.

Beden İmajı Ölçeği: Secord ve Jourand tarafindan geliştirilmiş (1953), Hovardaoğlu (1990) tarafından geçerlik ve güvenirliği yapılarak Türk topluma uyarlanmıştır. Ölçek, her biri bir organ ya da vücudun bir bölümü (kol, bacak, yüz gibi) ya da bir işlevi (cinsel faaliyet düzeyi gibi) ile ilgili toplam 40 maddeden oluşmaktadır. Her bir maddenin puanı 1'den 5'e kadar değişmektedir. Ölçeğin toplam puanı 40-200 arasındadır ve yüksek puan yüksek doyum düzeyini göstermektedir. Ölçeğin cronbach alfa katsayısı 0.91 olarak bulunmuştur $^{9}$. Çalışmamızda cronbach alfa katsayısı 0.94 bulundu.

Rosenberg Benlik Saygısı Ölçeği: Rosenberg (1965) tarafından geliştirilmiş ve Türkçe geçerlik ve güvenilirlik çalışması Çuhadaroğlu (1986) tarafından yapılmıştır. 63 sorudan oluşan likert tipinde bir öz değerlendirme ölçeğinin ilk on maddesi benlik saygısını değerlendirmek için kullanılmaktadır. Ölçek puanları 0-30 arasında değişmektedir ve puan yükseldikçe benlik saygısı yükselmektedir. Ayrıca ölçekten alınan puanlar, 30-26: maksimum düzeyde benlik saygısı, 15-25: normal benlik saygısı, 15 ve altı: azalmış benlik saygısı olarak değerlendirilmektedir. Ölçeğin geçerliliği yüksek olup, test-retest korelasyonu 0.82-0.88 arasında değişmektedir. Cronbach alfa katsayısı $0.77-$ 0.88 arasında bulunmuştur ${ }^{10,11}$. Çalışmamızda cronbach alfa katsayısı 0.86 olarak hesaplandı.

Anketler, katılımcıların kendileri tarafından yaklaşık 10-15 dakikada dolduruldu.

\section{İstatistiksel Analiz}

İstatistiksel analizler SPSS 20.0 programı kullanılarak yapıldı. Verilerin normal dağılım gösterip göstermediği Kolmogorov-Smirnov Z testi ile belirlendi. Veriler normal dağılım gösterdiğinden analizlerde parametrik testler kullanıldı. Kesikli değişkenler için yüzdelik ve karşılaştırmalarda ki-kare analizleri yapıldı. Sürekli değişkenlerin, iki grup karşılaştırmasında student $\mathrm{t}$ testi, ikiden fazla grup karşılaştırmasında çok yönlü varyans analizi ve değişkenler arasındaki ilişkinin incelenmesinde Pearson korelasyon analizlerinden yararlanıld1. İstatistiksel anlamlılık değeri $\mathrm{p}<0.05$ olarak kabul edildi.

\section{Etik Boyutu}

Çalışmanın etik kurul izni Klinik Araştırmalar Etik Kurulu'ndan alındı (Tarih: 20.02.2018 ve Karar No: 2018-4/20). Ayrıca çalışmaya dahil edilen hastalar ve sağlıklı bireylerden bilgilendirilmiş onam alındı.

\section{Bulgular}

Çalışmaya alınan hastaların ve sağlıklı bireylerin sosyodemografik özelliklerinin dağılımı Tablo I'de görülmektedir. Akut lösemi hastalarının yaş ortalaması 47.6 \pm 15.5 yıl, \%56's1 erkek, \%70.3'ü evli, \%43.5’i ilkokul mezunu idi. Hastaların \%73.6'sı çalışmadığını ve \%74.5’i orta düzeyde ekonomik duruma sahip olduğunu bildirdi (Tablo I). Hastaların hastalık süresi ortalamasının $47.64 \pm 15.53$ ay ve $\% 72.5$ 'inin hastalık tipinin akut miyeloid lösemi olduğu belirlendi. Akut lösemi hastalarının \%82.4'ünün hastalık hakkında, \%78.0'inin tedavi hakkında bilgi aldığ 1 saptandi. Hastaların \%64.8'i hastalığa uyum sağladığ 1 nı, \%61.5'i hastalığını "uzun süre tedavi gerektiren bir hastalık" olarak algıladığını, \%69.2'si tedaviye uyum sağladığını ve $\% 57.1$ 'i tedavinin olumsuz etkisini yaşadığını bildirdi (Tablo II).

Çalışmaya alınan bireylerde son zamanlarda yaşanan değişikliklerin gruplara göre dağılımı Tablo III'de gösterilmiştir. Lösemili hastaların $\% 50.5$ 'inin günlük aktivitelerinde, \%12.4'ünün aile hayatında, \%12.1'inin kişilerarası ilişkilerde ve \%24.2'sinin cinsel yaşamında son zamanlarda değişiklik yaşadığı saptand1. Akut lösemili bireylerin günlük aktiviteler, aile hayatı ve cinsel değişiklik yaşama oranlarının sağlıklı bireylerden anlamlı olarak yüksek olduğu belirlendi $(\mathrm{p}<0.05)$. Saç dökülmesi görülme oranı akut lösemi hastalarında \%63.7, sağlıklı bireylerde ise \%57.4 olarak bulundu ( $p>0.05)$. Saç dökülme oranı açısından gruplar arasında fark bulunmazken $(\mathrm{p}>0.05)$, saç dökülme şiddetinin lösemili bireylerde anlamlı olarak daha fazla olduğu saptand $1(\mathrm{p}=0.000)$.

Tablo I. Çalışmaya alınan bireylerin sosyodemografik özelliklerinin dağılımı

\begin{tabular}{|c|c|c|c|}
\hline & $\begin{array}{l}\text { Lösemili Birey } \\
\text { n (\%) }\end{array}$ & $\begin{array}{c}\text { Sağlıklı Birey } \\
\text { n (\%) }\end{array}$ & $p$ \\
\hline Yaş - yıl (ortalama $\pm S S$ ) & $47.64 \pm 15.53$ & $35.18 \pm 12.79$ & 0.000 \\
\hline $\begin{array}{r}\text { Cinsiyet } \\
\text { Kadın } \\
\text { Erkek }\end{array}$ & $\begin{array}{l}40(44.0) \\
51(56.0)\end{array}$ & $\begin{array}{l}70(74.5) \\
24(25.5)\end{array}$ & 0.000 \\
\hline $\begin{array}{c}\text { Medeni Durum } \\
\text { Evli } \\
\text { Bekar }\end{array}$ & $\begin{array}{l}64(70.3) \\
27(29.7)\end{array}$ & $\begin{array}{l}50(53.8) \\
43(46.2)\end{array}$ & 0.332 \\
\hline $\begin{array}{l}\text { Eğitim Durumu } \\
\text { İlkokul } \\
\text { Ortaokul } \\
\text { Lise } \\
\text { Üniversite }\end{array}$ & $\begin{array}{l}37(43.5) \\
13(15.3) \\
17(20.0) \\
18(21.2)\end{array}$ & $\begin{array}{c}21(21.5) \\
2(2.2) \\
20(21.5) \\
50(53.8)\end{array}$ & 0.000 \\
\hline $\begin{array}{c}\text { Çalışma Durumu } \\
\text { Evet } \\
\text { Hayır }\end{array}$ & $\begin{array}{l}23(26.4) \\
64(73.6)\end{array}$ & $\begin{array}{l}76(85.4) \\
13(14.6)\end{array}$ & 0.000 \\
\hline $\begin{array}{l}\text { Ekonomik Durum } \\
\text { İyi } \\
\text { Orta } \\
\text { Kötü }\end{array}$ & $\begin{array}{c}20(22.2) \\
67(74.5) \\
3(3.3)\end{array}$ & $\begin{array}{c}22(24.4) \\
61(67.8) \\
7(7.8)\end{array}$ & 0.372 \\
\hline Toplam & $91(100.0)$ & $94(100.0)$ & \\
\hline
\end{tabular}


Tablo II. Çalışmaya alınan akut lösemili bireylerin hastalık özelliklerinin dağılımı

\begin{tabular}{|c|c|}
\hline & $\begin{array}{c}\text { Lösemili Birey } \\
\mathrm{n}(\%)\end{array}$ \\
\hline Hastalık süresi - ay (ortalama $\pm S S$ ) & $47.64 \pm 15.53$ \\
\hline $\begin{array}{l}\text { Hastalık tipi } \\
\text { Akut Lenfoblastik Lösemi } \\
\text { Akut Miyeloid Lösemi }\end{array}$ & $\begin{array}{l}25(27.5) \\
66(72.5)\end{array}$ \\
\hline $\begin{array}{l}\text { Hastalık hakkında bilgi alma } \\
\text { Evet } \\
\text { Hayır }\end{array}$ & $\begin{array}{l}75 \text { (82.4) } \\
16(17.6)\end{array}$ \\
\hline $\begin{array}{l}\text { Tedavi hakkında bilgi alma } \\
\text { Evet } \\
\text { Hayır }\end{array}$ & $\begin{array}{l}71(78.0) \\
20(22.0)\end{array}$ \\
\hline $\begin{array}{l}\text { Hastalığa uyum sağlama } \\
\text { Evet } \\
\text { Hayır } \\
\text { Kısmen }\end{array}$ & $\begin{array}{l}59(64.8) \\
12(13.2) \\
20(22.0)\end{array}$ \\
\hline $\begin{array}{l}\text { Hastalığı algılama } \\
\text { Tedavi edilemeyen bir hastalık } \\
\text { Uzun süre tedavi gerektiren bir hastalık } \\
\text { Kolay tedavi edilen bir hastalık } \\
\text { Fikrim yok }\end{array}$ & $\begin{array}{c}6(6.6) \\
56(61.5) \\
7(7.7) \\
22(24.2)\end{array}$ \\
\hline $\begin{array}{l}\text { Tedaviye uyum sağlama } \\
\text { Evet } \\
\text { Hayır } \\
\text { KIsmen } \\
\end{array}$ & $\begin{array}{c}63(69.2) \\
9(9.9) \\
19(20.9)\end{array}$ \\
\hline $\begin{array}{l}\text { Tedavinin olumsuz etkisi } \\
\text { Evet } \\
\text { Hayır }\end{array}$ & $\begin{array}{l}52(57.1) \\
39(42.9)\end{array}$ \\
\hline Toplam & $91(100.0)$ \\
\hline
\end{tabular}

Tablo III. Çalışmaya alınan bireylerde son zamanlarda yaşanan değişikliklerin gruplara göre dağılımı

\begin{tabular}{|c|c|c|c|}
\hline & $\begin{array}{c}\text { Lösemili Birey } \\
n(\%)\end{array}$ & $\begin{array}{c}\text { Sağlıklı Birey } \\
\mathrm{n}(\%)\end{array}$ & $\mathrm{p}$ \\
\hline $\begin{array}{r}\text { Günlük aktiviteler } \\
\text { Değişiklik var } \\
\text { Değişiklik yok }\end{array}$ & $\begin{array}{l}46(50.5) \\
45(49.5)\end{array}$ & $\begin{array}{l}17(18.1) \\
77(81.9)\end{array}$ & 0.000 \\
\hline \begin{tabular}{|l} 
Aile hayatı \\
Değişiklik var \\
Değişiklik yok
\end{tabular} & $\begin{array}{l}16(17.6) \\
75(82.4)\end{array}$ & $\begin{array}{c}7(7.8) \\
87(82.2)\end{array}$ & 0.032 \\
\hline $\begin{array}{c}\text { Kişilerarası ilişkiler } \\
\text { Değişiklik var } \\
\text { Değişiklik yok } \\
\end{array}$ & $\begin{array}{l}11(12.1) \\
80(81.9)\end{array}$ & $\begin{array}{l}10(10.6) \\
54(89.4)\end{array}$ & 0.468 \\
\hline \begin{tabular}{|l} 
Cinsel yaşam \\
Değisisiklik var \\
Değişiklik yok
\end{tabular} & $\begin{array}{l}22(24.2) \\
69(75.8)\end{array}$ & $\begin{array}{c}6(6.4) \\
88(93.6)\end{array}$ & 0.001 \\
\hline $\begin{array}{l}\text { Saç Dökülmesi } \\
\text { Var } \\
\text { Yok }\end{array}$ & $\begin{array}{l}58(63.7) \\
33(36.3)\end{array}$ & $\begin{array}{l}54(57.4) \\
40(42.6)\end{array}$ & 0.234 \\
\hline $\begin{array}{l}\text { Saç dökülmesinin şiddeti } \\
\text { Aşırı-Gözle rahatlıkla } \\
\text { görülebilir } \\
\text { Hafif-Gözle belli } \\
\text { belirsiz görülebilir }\end{array}$ & $\begin{array}{c}\mathrm{n}=58 \\
49(84.5) \\
9(15.5)\end{array}$ & $\begin{array}{c}\mathrm{n}=54 \\
11(20.4) \\
43(79.6)\end{array}$ & 0.000 \\
\hline Toplam & $91(100.0)$ & $94(100.0)$ & \\
\hline
\end{tabular}

Çalışmaya alınan bireylerin genel sağlık puan ortalamaları açısından iki grup arasında fark olmadığı saptandı $(\mathrm{p}>0.05)$. Benlik saygısının, hastalardan saç dökülmesi yaşayanlarda daha düşük $(\mathrm{p}<0.05)$ olduğu belirlenirken, sağlıklı grupta fark olmadığı belirlendi ( $>0.05)$. Her iki grup arasında benlik saygısı açısından fark bulunmazken, beden imajı açısından anlamlı fark saptand $1(p=0.000)$ (Tablo IV). Çalışmaya alınan bireylerin yaşları ile genel sağlık ve beden imajı arasinda negatif korelasyon olduğu belirlenirken $(\mathrm{p}<0.05)$, benlik saygısı arasında ilişki saptanmadı $(\mathrm{p}>0.05)$. Saç dökülmesi yaşayan hastaların kemoterapiye bağlı alopeside yaşam kalitesi puanı ile benlik saygısı $(\mathrm{r}=0.264, \mathrm{p}=0.045)$ arasında pozitif korelasyon saptandı. Genel sağlık puanı ile beden imajı ve benlik saygısı puanları arasında pozitif ilişki saptanırken, beden imajı ile benlik saygısı arasında da pozitif korelasyon olduğu belirlendi $(\mathrm{p}<0.001)$ (Tablo V).

Tablo IV. Çalışmaya alınan bireylerin genel sağlık, beden imajı ve benlik saygisı puan ortalamalarının gruplara göre dağılımı

\begin{tabular}{|c|c|c|c|}
\hline & $\begin{array}{l}\text { Genel sağlık } \\
\text { ortalama } \pm S S\end{array}$ & $\begin{array}{l}\text { Beden imajı } \\
\text { ortalama } \pm S S\end{array}$ & $\begin{array}{l}\text { Benlik saygısı } \\
\text { ortalama } \pm S S\end{array}$ \\
\hline \multicolumn{4}{|l|}{ Lösemili Birey } \\
\hline Alopesi var & $6.26 \pm 2.25$ & $162.00 \pm 21.26$ & $19.87 \pm 3.91$ \\
\hline Alopesi yok & $6.51 \pm 2.00$ & $161.66 \pm 17.45$ & $21.65 \pm 4.19$ \\
\hline$p$ & 0.604 & 0.939 & 0.047 \\
\hline \multicolumn{4}{|l|}{ Sağlıklı Birey } \\
\hline Alopesi var & $7.24 \pm 2.43$ & $152.38 \pm 27.68$ & $22.18 \pm 6.80$ \\
\hline Alopesi yok & $6.37 \pm 1.90$ & $144.12 \pm 28.82$ & $20.65 \pm 4.55$ \\
\hline$p$ & 0.065 & 0.166 & 0.194 \\
\hline Gruplararası $p$ & 0.120 & 0.000 & 0.491 \\
\hline
\end{tabular}

Tablo V. Çalışmaya alınan hastaların bazı özellikleri ile genel sağlık, beden imajı ve benlik saygisı puanlarının korelasyonu

\begin{tabular}{|c|c|c|c|c|c|c|}
\hline & \multicolumn{2}{|c|}{ Genel sağlık } & \multicolumn{2}{|c|}{ Beden imajı } & \multicolumn{2}{|c|}{$\begin{array}{l}\text { Benlik } \\
\text { saygısı }\end{array}$} \\
\hline & & $\mathrm{p}$ & & & $r$ & $p$ \\
\hline Yaş & -0.272 & 0.000 & 0.044 & $0.548-$ & 0.202 & 0.006 \\
\hline Beden kitle indeksi & -0.188 & 0.018 & -0.014 & 0.858 & -0.109 & 0.160 \\
\hline Hastalık süresi & -0.034 & 0.763 & -0.106 & 0.339 & 0.054 & 0.628 \\
\hline KBAYKÖ & -0.055 & 0.687 & 0.196 & 0.140 & 0.264 & 0.045 \\
\hline Genel sağlık & - & - & 0.355 & 0.000 & 0.407 & 0.000 \\
\hline Beden imajı & 0.355 & 0.000 & - & - & 0.298 & 0.000 \\
\hline
\end{tabular}

\section{Tartışma}

Akut lösemi hastalarında alopesinin beden imajı ve benlik saygısına etkisini belirlemek amacıyla planlanan çalışmada, alopesi görülme oranının akut lösemi hastalarında \%63.7 ve alopesi düzeyinin hastaların \%84.5'inde gözle açıkça görülebilir şekilde olduğu saptand. Alopesili akut lösemi hastaların yaşam kalitesinin iyi düzeyde olduğu belirlenirken, benlik sayg1sının daha düşük olduğu ve beden imajının değişmediği saptandı. Hastaların genel sağlık puanı ile benlik 


\section{Akut Lösemi ve Alopesi}

saygısı ve beden imajı arasında pozitif ilişki olduğu belirlendi. Akut lösemi hastalarında genel sağlık ile ilişkisi göz önüne alındığında, alopesinin hastalar üzerindeki olumsuz etkilerinin ve özellikle de kendini gerçekleştirmede önemli olan benlik saygısı ve beden imajının değerlendirilmesinin gerektiği düşünülmektedir.

Kişiselliğin temel parçalarından biri olan saç, kișinin özel görünmesini sağlar. Boyanarak, kestirilerek, şekil verilerek istenilen özelliklere büründürülebildiğinden, imaj oluşumunda ve değişiminde kişinin hayatında önemli bir yeri vardır ${ }^{12}$. Nedeni ne olursa olsun saçta istenmeyen değişimler ve özellikle de saç dökülmesi, kişide uyum bozukluğu, anksiyete, sosyal izolasyon, davranım bozukluğu, somatik veya seksüel işlev bozukluğu, suçluluk, beden imajından memnuniyetsizlik, depresyon gibi ciddi sorunlara neden olabilmektedir $^{13,14}$. Özellikle kanser nedeniyle kemoterapi alan hastalarda görülen alopesi, hastalığın etkilerinin görülebilir hale gelerek dış çevre tarafından algılanmasına olanak sağladığından kişide travmaya neden olmaktadır. Alopesiye verilen yanıt kişinin algısı, hastalığa ve saçına yüklediği anlam ile ilişkili olmakla birlikte, beden imajı ve benlik saygısının ön plana çıkmasına neden olduğundan yaşanan olumsuz duyguların sebebi olabilmektedir ${ }^{15}$. Irmak ve arkadaşları (2008) kemoterapi uygulanan hastalarda saç kaybının en önemli üzüntü kaynağı olduğunu, tedaviden sonra saçlar yeniden çıksa da, geçici saç kaybının bile hastalarda büyük bir travmaya neden olduğunu bildirmektedir ${ }^{16}$. Zihinsel olarak hazır olsalar da, tarağa gelen ve yast1ğa dökülen saç demetleri ile karşılaşan hastaların şok yaşadıkları belirtilmektedir ${ }^{17}$. Kemoterapi uygulanan kanser hastalarının \%70.9'unda gözle görülebilir saç dökülmesinin olduğu belirlenirken, kadınların, ek hastalığı olanların ve sağlığını kötü olarak algılayanların KBAYKÖ puan ortalamasının anlamlı olarak daha düşük olduğu saptanmıştır ${ }^{3}$. Çalıșmamızda ise, alopesi görülme oranının $\% 63,7$ ve saç dökülmesi şiddetinin \%84,5'inde açıkça gözle görülebilir şekilde olduğu belirlendi. Ayrıca, sosyodemografik özellikler ve genel sağlık ile KBAYKÖ arasında ilişki bulunmazken, benlik saygısı ile pozitif korelasyon saptand1 $(\mathrm{p}<0.05)$. Bu sonuçlar, kemoterapi uygulanan lösemili hastalarda alopesinin önemli bir sorun olduğunu, ayr1ca yaşam kalitesinde azalmaya ve psikososyal sorunlara neden olabileceğini göstermektedir.

Beden imajı, kişinin bedenini kendi zihninde nasıl canlandırdığını göstermekle birlikte, sosyal etkileşimlerden etkilenmektedir ${ }^{18,19}$. İnsanın yaşamı boyunca kendine saygı ve zihinsel sağlı̆̆ı önemli bir bileşeni olan beden imajı, kendini kabullenme, sosyal özgüven ve karşı cins tarafından çekici olma ile ilişkili olduğundan oldukça önemlidir ${ }^{7}$. Kanser hastalarına uygulanan tedaviler sonucu kaybedilen işlevler veya organlara bağlı olarak hastalarda bozulmuş benlik saygısı ve beden imajı sıklıkla görülebilmektedir². Jinekolojik ve meme kanserli hastalar ile yapılan çalışmalarda, kanser hastalarında beden imajının bozulduğu bildirilmektedir ${ }^{7,20,21}$. Hematolojik malignitesi olan hastalarda yapılan bir çalışmada, beden imajının sadece cinsiyetten etkilendiği, kadınlarda daha düşük olduğu belirlenmiştir ${ }^{4}$. Çalışmamızda, lösemili hastaların beden imajı puan ortalamasının yüksek olduğu ve alopesiden etkilenmediği saptand1. Bu sonuç, alopesinin tedavinin geçici etkisi olarak ortaya çıkmasından kaynaklanabilir. Meme ve jinekolojik kanserlerde, kişinin vücut görüntüsünde yaşanan kalıcı değişiklikler, üreme/cinselliğin olumsuz etkilenmesi ve kendini daha az çekici hissetmesi gibi olumsuz durumların beden imajını daha fazla etkilediği düşünülmektedir.

Benlik saygısı; kişinin benliğine yönelik geliştirdiği olumlu/olumsuz tutumları veya kendini ne kadar değerli hissettiğini ifade etmektedir ${ }^{22}$. Vücut bütünlüğünün gözle görülebilir şekilde bozulduğu durumlarda (romatoid artrit, meme kanseri, jinekolojik kanserler, vb.), benlik saygısının azaldığ rın arttığı bildirilmiştir ${ }^{7,19}$. Üstündağ ve arkadaşlarının (2011) çalışmasında, jinekolojik kanserli kadınların benlik saygısının düşük olduğu belirlenmiştir ${ }^{7}$. Lösemi hastaları ile yapılan iki farklı çalışmada, lösemi hastalarının umutsuzluk düzeyinin yüksek olduğu ve yaşanan bu olumsuz duygunun benlik saygısı ile ilişkili olduğu saptanmıştır ${ }^{2,8}$. Çalışmamızda, alopesinin hastaların benlik saygısında azalmaya neden olduğu, benlik saygısının genel sağlık ve yaşam kalitesi ile ilişkili de olduğu belirlendi. Bu sonuçlar doğrultusun$\mathrm{da}$, hemşirelerin hastalık, tedaviler ve semptomların yönetimi konusunda vereceği eğitimlerin lösemi hastalarının umudunu, yaşam kalitesini ve benlik saygısını arttırmada oldukça önemli olduğu düşünülmektedir.

Düşük beden imajı ve benlik saygısına sahip bireylerin tedavide işbirliği yapmadıkları, sosyal ilişkilerinin sınırlı ve özgüvenlerinin düşük olduğu, hastalıkla mücadele etmeyi bırakmaya meyilli olduklarından, beden imajı ve benlik saygısı düzeylerinin önemli olduğu vurgulanmaktadır ${ }^{19}$. Kemoterapi tedavisi planlanan hastaların bazıları, sadece alopesi nedeniyle tedavi olmayı reddedebilmektedir. Ancak tedaviye başlandıktan sonra ortaya çıkan saç dökülmesinden 46 hafta sonra saçların tekrar uzadığı belirtilmektedir ${ }^{3}$. Beden imajı ve benlik saygısının bozulduğu durumlarda, olumsuz etkilenmenin azaltılabilmesi için işlevsel olan hasta fonksiyonlarının desteklenmesi, yeterli bilgilendirme ve erken psikososyal desteğin sağlanması gerekmektedir ${ }^{6}$. Eğitici ve destekleyici psikolojik bakımın hastaların özgüven ve özsaygısını arttırdığ 1 bildirilmektedir ${ }^{4}$. Alopesi deneyimleyen hastalara etkili destek sağlanabilmesi için bu durumu yaşamanın nasıl bir şey olduğunu iyi anlamak gerekir. Alopesi hızlı geliştiğinde kişinin kimliğine yönelik sıkıntı ve tehdit deneyimlediği, etkili başa çıkma stratejileri geliştirmek için mücadele ederken de utanç ve tecrit duyguları yaşadığı bildirilmiştir. Sosyal destek alope- 


\section{S. Pehlivan, ark.}

sinin psikolojik etkisinin iyileştirilmesine yardımcı olabilecekken, bozulmuş sosyal işlevsellik ve sağlik çalışanlarının yetersiz destekleri nedeniyle sosyal desteğe istenilen düzeyde ulaşılamamaktadır ${ }^{23}$. Literatürde, uygulanan tedaviye bağlı saç dökülmesi beklenen hastalarda görülen olumsuz duygu ve düşüncelerin azaltılabilmesi için; önceden bilgilendirilmesi ve saçlarını tamamen kestirme veya bir peruk alma konusunda önerilerin sunulması gerektiği belirtilmektedir ${ }^{17}$. Yapılan çalışmalarda, hastaların yarısının alopesiyi gizleyici materyaller (eşarp, bone, bere, şapka) kullandıkları belirtilmektedir ${ }^{24,25}$. Saç dökülmesini gizlemek için yaygın olarak kullanılan bu yöntemler kendine güveni artırabilir, ancak fark edilme ile ilgili endişeler kaygıyı artırabilir, yetersizlik duygusu yaratabilir ve sosyal faaliyetlerden kaçınmaya neden olabilir. Bu nedenle hastalara verilecek psikososyal destek hem yaşanan duygular hem de süreç ile başa çıkma açısından oldukça önemlidir ${ }^{23}$.

Sonuç olarak akut lösemi hastalarının yarısından çoğunda tedavinin yan etkilerinden olan alopesinin görüldüğü ve alopesili hastaların yaşam kalitesinin iyi düzeyde olduğu belirlendi. Alopesinin akut lösemi hastalarında benlik saygısını olumsuz etkilediği, beden imajını etkilemediği saptandı. Akut lösemi hastalarında genel sağlık ile ilişkisi göz önüne alındığında, alopesinin hastalar üzerindeki etkisi, benlik saygısı ve beden imajının değerlendirilmesinin önemli olduğu düşünülmektedir. $\mathrm{Bu}$ çalışmanın sonucunda akut lösemi hastalarında alopesinin, beden imajı ve benlik saygısına yönelik olumsuz etkilerine dikkat çekilmiştir. Alopesi riski olan bireylere erken psikososyal destek ve danışmanlık hizmetleri verilerek bu olumsuz etkilerin azaltılabileceği düşünülmektedir. Böylece alopesiye bağlı ortaya çıkan beden imajı ve benlik saygısındaki olumsuz etkilerin genel sağlık üzerine etkileri de azaltılabilecektir.

\section{Kaynaklar}

1. Sencan İ, İnce GN. Türkiye Kanser İstatistikleri. T.C. Sağlık Bakanlığı, Türkiye Halk Sağlığı Kurumu, Ankara, 2016.

2. Parvan K, Tabrizi FJ, Rahmani A, Ghojazadeh M, Azadi A, Golchin M. The relationship between hope and self-esteem in patients with leukemia. Journal of Caring Sciences 2015;4:21723

3. Ateş S, Olgun N. Kemoterapiye bağlı alopesi ve yaşam kalitesi. Hacettepe Üniversitesi Hemşirelik Fakültesi Dergisi 2014;6780

4. Zucchetti G, Bellini S, Bertolotti M, et al. Body ımage discomfort of adolescent and young adult hematologic cancer survivors. J Adolesc Young Adult Oncol 2017;6:377-80.

5. Guerra-Tapia A, Gonzalez-Guerra E. Hair cosmetics: dyes. Actas Dermosifiliogr 2014;105:833-9.
6. Weber CS, Fliege H, Arck PC, Kreuzer KA, Rose M, Klapp BF Patients with haematological malignancies show a restricted body focusing on function and emotion. Eur $\mathrm{J}$ Cancer Care (Engl) 2005;14:155-65.

7. Üstündağ MF, Özcan H, Yazla E, Kıvrak Y, Aydın EF, Yılmaz M. Anxiety and depression symptoms, self-esteem and body image among patients with gynecological cancers: a crosssectional study. Kafkas J Med Sci 2017;7:214-9.

8. Geihman G, Zimmermann C, Deckert A, et al. Depression and hopelessness in patients with acute leukemia: the psychological impact of an acute and life-threatening disorder. Psychooncology 2016;25:979-89.

9. Hovardaoğlu S. Vücut Algısı Ölçeğinin Güvenirlik Ve Geçerlik Çalışması/Şizofrenik Ve Majör Depresif Hastaların Beden İmgelerinden Doyum Düzeyleri (Yüksek Lisans Tezi). Ankara: Gazi Üniversitesi; 1990.

10. Rosenberg M. Society and the adolescent self-image. Priceton, NJ: Priceton University Press; 1965

11. Çuhadaroğlu F. Adölesanlarda Benlik Saygısı (Tıpta Uzmanlık Tezi). Ankara: Hacettepe Üniversitesi, 1986.

12. Cash TF. The psychology of hair loss and its implications for patient care. Clin Dermatol 2001;19:161-6.

13. Harth W, Blume-Peytavi U. Psychotrichology: psychosomatic aspects of hair diseases. J Dtsch Dermatol Ges 2013;11:125-35.

14. Trüeb RT. The difficult hair loss patient: a particular challenge. Int J Trichol 2013;5:110-4.

15. Kara B, Fesci H. Kanserde öz-bakım ve yaşam kalitesi. Hematoloji-Onkoloji 2004;6:124-9.

16. Irmak MK, Bilgin MG, Stzlan A. Hasta gözüyle kanser. Koruyucu Hekimlik 2008;7:167-72.

17. MacDonald P. Supporting patients with alopecia. Practice Nurse 2007;33:46.

18. Doğan T, Sapmaz F, Totan T. Beden imgesi baș etme stratejileri ölçeğinin türkçe uyarlaması: geçerlilik ve güvenilirlik çalışmasi. Anadolu Psikiyatri Dergisi 2011;12:121-9.

19. Kurt E, Özdilli K, Yorulmaz H. Romatoid artritli hastalarda beden imajı ve benlik saygısı. Nöropsikiyatri Arşivi 2013;50:202-8.

20. Gümüs $A B$, Çam $O$. Relationships between early diagnosis attitudes in cervical cancer of women and levels of self-esteem, body perception and hopelessness. Nobel Med 2011;7:46-52.

21. Denizgil T, Sönmez İ. Meme kanseri nedeni ile meme koruyucu cerrahi geçirmiş kadınlarla mastektomi operasyonu geçirmiş kadınlar arasında benlik saygısı, beden algısı, cinsel doyum ve cinsel yaşantılar üzerine etkisi. Yeni Symposium 2015;53:17.

22. Kutanis Özen R. Tunç T. Hemşirelerde benlik saygısı ile durumluk ve sürekli kaygı arasındaki ilişki: bir üniversite hastanesi örneği. "İ̧̧, Gü̈ç" Endüstri İlişskileri ve İnsan Kaynakları Dergisi 2013;15:1-15.

23. Davey L, Clarke V, Jenkinson E. Living with alopecia areata: an online qualitative survey study. Br J Dermatol 2018;doi: 10.1111/bjd.17463.

24. Hintistan S, Çilingir D, Nural N, Gürsoy A. Hematolojik kanserli hastaların kemoterapiye bağlı yaşadıkları semptomlara yönelik uygulamaları. Gümüşhane Üniversitesi Sağlık Bilimleri Dergisi 2012;1:153-64.

25. Ünsar S, Fındık ÜY, Kurt S, Özcan H. Kanserli hastalarda evde bakım ve semptom kontrolü. Fırat Sağlı Hizmetleri Dergisi 2007;2:89-106 